\title{
Pilot Plant Optimization for Alcohol Production in Fermentation of an Opaque Beer by Varying Sieve Size
}

\author{
Zvidzai $\mathbf{C J}^{1 *}$, Chidewe $\mathrm{C}^{2}$, Mubaiwa $\mathrm{J}^{1}$, Tinofa $\mathrm{S}^{3}$, Manjeese $\mathbf{W}^{1}$ and Musundire $\mathbf{R}^{1}$
}

${ }^{1}$ Chinhoyi University of Technology, Off Chirundu Road, Bag 7724, Chinhoyi, Zimbabwe

${ }^{2}$ Biochemistry Department, University of Zimbabwe, Box MP167, Mt. Pleasant, Harare, Zimbabwe

${ }^{3}$ Chibuku Breweries, P.O. Box 3304, Harare, Zimbabwe

\begin{abstract}
The effect of mesh sieve sizes; $0.84 \mathrm{~mm}, 1.0 \mathrm{~mm}$ and $1.19 \mathrm{~mm}$ on alcohol concentration, free reducing sugars profile and total acids produced was determined during opaque beer fermentation. The initial free reducing sugars increased from $7.23 \pm 0.1 \mathrm{mmol} / \mathrm{ml}$ to $7.52 \pm 0.03 \mathrm{mmol} / \mathrm{ml}$ and $7.67 \pm 0.03 \mathrm{mmol} / \mathrm{ml}$ values as the sieve size decreased. Meanwhile, the final alcohol concentration attained for each fermentation reached leveled off after 72 $\mathrm{hr}$ producing $3.57 \pm 0.06 \%(\mathrm{v} / \mathrm{v}), 4.09 \pm 0.29(\mathrm{v} / \mathrm{v}) \%$ and $4.23 \pm 0.25(\mathrm{v} / \mathrm{v}) \%$ in order of decreasing mesh sieve size translating to a volumetric productivity of $0.49,0.54$ and $0.61 \mathrm{~g}^{-1} \mathrm{I}^{-1} \mathrm{~h}^{-1}$, respectively. Use of $1.0 \mathrm{~mm}$ grinding sieve produced a final ethanol concentration which increased by $9 \%$ compared to that of $1.19 \mathrm{~mm}$ and $23 \%$ to that of 0.84 $\mathrm{mm}$ sieve. This realized a Yp/s value increase of $2 \%$ with the use of $1.0 \mathrm{~mm}$ sieve and $4 \%$ with $0.84 \mathrm{~mm}$. The final organic acids determined as lactic acid composition were noted to increase from $0.46 \pm 0.01(\mathrm{w} / \mathrm{v}) \%, 0.48 \pm 0.01$ $(\mathrm{w} / \mathrm{v}) \%$ and $0.5 \pm 0.02(\mathrm{w} / \mathrm{v}) \%$ concentration as the sieve size decreased respectively. However, in all brews, the final $\mathrm{pH}$ was noted to be of no significant difference $(P>0.05)$ dropping from around the same initial $\mathrm{pH}$ value of 5.9 to 3.3. The opaque beer brew prepared with a mesh sieve size 0.84 had its initial free reducing sugars the highest and produced a brew with the highest final ethanol concentration that levelled off at $4.23 \pm 0.25(\mathrm{v} / \mathrm{v}) \%$ after $120 \mathrm{hr}$. However, it was noted that mesh sieve size $1.0 \mathrm{~mm}$, although it had a lower alcohol content compared to 0.84 , it was recommended as an optimized maize grits because it produced an opaque beer product which was consistent and of acceptable palatability to the analysis of sensory evaluation.
\end{abstract}

Keywords: Optimization; Mesh sieve size; Fermentation; Lactic acid and alcohol

\section{Introduction}

Sorghum (Sorghum bicolor [L.] Moench) is an important food crop grown in arid and semi-arid regions of the world [1,2]. Brewing of beer making use of sorghum back dates to times immemorial and is practiced in a number of African countries [3]. Cereal grains like sorghum, maize and millet have been in use as for sorghum beer fermentation, other cereals like maize have been commercially adopted as adjuncts for lactic acid-fermented gruels and beverages [4-7]. Cereals are known and documented to supply majority of the dietary protein, calories, vitamins, and minerals to a number of populations in developing nations $[8,9]$. Fermented sorghum or millet-based foods, alcoholic and non-alcoholic drinks or beverages are commercially prepared at household level in many African countries for human consumption [7,10-12].

The commercial process involves making use of maize grits which are added as adjuncts in the fermentation of sorghum beer. Maize grits are produced making use of a sieve size which has been recommended for commercial purpose. However, the understanding of the maize grits coming from a particular Sauter mean diameter sieve size would bring changes during brewing in starch swelling and solubilisation, amylolysis heat transfer and sugar availability [13]. This has been assumed to be an innovative development in brewing industry [14]. Although sorghum is an extremely important commercial crop of many people in developing countries, use of different genotype varieties affect the ethanol and lactic acid production of sorghum beverages and is used mainly for its high diastatic activity [15-17].

This study was undertaken to analyze the increase the efficiency of starch liquefaction and saccharification when sieve size used for maize grits adjuncts was adjusted from $0.84 \mathrm{~mm}$ to $1.0 \mathrm{~mm}$ and 1.19 $\mathrm{mm}$, on fermentation parameters during brewing of opaque beer using a 20 liter working volume pilot bioreactor. The project focused at improving on alcohol levels in the opaque beer compared to the currently commercialized one.

\section{Materials and Methods}

\section{Raw materials and their sources}

Raw materials used were white maize meal, lactic acid of $10 \%$ $(w / w)$, sorghum grain, sorghum malt and yeast these were obtained from the commercial producing companies. The straight run maize meal was used as an adjunct. Industrially malted sorghum grain from Delta Beverages, Aspindale Plant, Harare, Zimbabwe was used for all the brews. Commercially prepared lactic acid (10 (v/v)\%) and yeast were used for test brews. A hammer mill for preparing maize adjuncts was used with the following mesh size $0.84 \mathrm{~mm}, 1.0 \mathrm{~mm}$ and $1.19 \mathrm{~mm}$ nominal aperture size.

\section{The pilot brewing process}

A pilot scale of 30 liter stainless steel vessel with a working volume

*Corresponding author: Zvidzai CJ, Chinhoyi University of Technology, Off Chirundu Road, Bag 7724, Chinhoyi, Zimbabwe, Tel: 263-67-22203-5; Fax: 263 67-26321; E-mail: czvidzai@cut.ac.zw

Received February 25, 2014; Accepted February 26, 2014; Published March 05, 2014

Citation: Zvidzai CJ, Chidewe C, Mubaiwa J, Tinofa S, Manjeese W, et al. (2014) Pilot Plant Optimization for Alcohol Production in Fermentation of an Opaque Beer by Varying Sieve Size. Ferment Technol 3: 111. doi:10.4172/2167-7972.1000111

Copyright: @ 2014 Zvidzai CJ, et al. This is an open-access article distributed under the terms of the Creative Commons Attribution License, which permits unrestricted use, distribution, and reproduction in any medium, provided the original author and source are credited. 
of 20 liters fermentation medium was used in all brews. The control brew which makes use of mesh size 16 was run concurrently. The brewing process is described elsewhere [18]. The standard raw material quantities for the $20 \mathrm{~L}$ brew volume was $233 \mathrm{~g}$ milled maize adjunct, 66 ml lactic acid and $200 \mathrm{~g}$ sorghum grain. These raw materials were steeped and cooked for 1 hour at boiling temperature. A pH of between 3.5 and 4.0 was aimed upon addition of lactic acid. The mashing process was done prior to cooling down the cooked adjunct to $54^{\circ} \mathrm{C}$. An amount of $106 \mathrm{~g}$ of sorghum malt was added at $54^{\circ} \mathrm{C}$. The brews were held at this temperature for 60 minutes. The temperature was raised to $70^{\circ} \mathrm{C}$ at the end of first conversion. Straining was done using a mesh 16 sieve size. This mash was pasteurized at $80^{\circ} \mathrm{C}$ after straining. The temperature was raised to $85^{\circ} \mathrm{C}$. At the end of pasteurization the wort was cooled down to $64^{\circ} \mathrm{C}$. Second conversion was done differently on the control brews and the experimental brews. Control and experimental brews made use of $33.5 \mathrm{~g}$ of sorghum malt during the second conversion phase. The wort was cooled down to $28^{\circ} \mathrm{C}$. A quantity of $2.0 \mathrm{~g}$ of active dried yeast was added to each brew and allowed to ferment for $120 \mathrm{hr}$ meanwhile collecting samples at $24 \mathrm{hr}$ interval. All the experiments were carried out in triplicates and the mean value of the results were recorded.

\section{Iodometric determination of sugars}

The sugars that were produced by the malt extract were estimated by boiling $5.0 \mathrm{ml}$ of the aliquot of the solution with $10.0 \mathrm{ml}$ of $0.05 \mathrm{M}$ potassium ferricyanide and the unchanged ferricyanide was determined by titration against $0.05 \mathrm{M}$ sodium thiosulphate solution with $50 \%$ potassium iodide being the indicator. The unchanged ferricyanide was determined by titration. A blank was carried out in order to make allowance for sugars that are already in the malt extract [19].

\section{Determination of $\mathrm{pH}$}

$\mathrm{pH}$ was measured using a Jenway $3520 \mathrm{pH}$ meter at room temperature.

\section{Determination of Total acidity/ titratable acidity}

Titratable acidity was done as outlined in the Delta Beverages, 2000 user manual [18]. Each beer sample of $100 \mathrm{ml}$ volume was filtered through a Whatman No. 1 filter paper. A volume of $10 \mathrm{ml}$ of the filtrate was titrated against $0.1 \mathrm{~N} \mathrm{NaOH}$ using phenolphthalein indicator until a permanent pink colour persisted for 30 seconds. The titration was done in triplicate for each sample. The total acidity was then calculated by multiplying the obtained titrant volume by 0.09 . It must be noted that 0.09 is a conversion factor used to change total acids from grams to percentages.

\section{Determination of alcohol content by specific gravity in beer sample}

A well mixed beer sample was measured into a $100 \mathrm{ml}$ volumetric flask. The sample was then transferred into a distillation flash into which $100 \mathrm{ml}$ of tape water were also added. Distillation was done until 100 $\mathrm{ml}$ of distillate were collected. The sample was cooled to $20^{\circ} \mathrm{C}$ before the relative density, measured as specific gravity, was determined by filling a standardized Specific Gravity (SG) bottle and weighing it. The amount of alcohol was then determined from the specific gravity conversion tables as percentages by volume [19].

$$
\text { specific gravity }=\frac{\text { weight of SG bottle plus distillate }- \text { weight of empty SG bottle }}{\text { weight of distilled water }}
$$

\section{Determination of yeast and lactobacilli in brews}

Malt extract agar was prepared per manufacturer's instruction on the media bottle and $10 \mathrm{ml}$ of $10 \%(\mathrm{w} / \mathrm{v})$ lactic acid solution per liter of the media. Serial dilutions of beer samples aged 48 hours were performed to the $8^{\text {th }}$ factor dilution. Using a sterile pipette $1.0 \mathrm{ml}$ of the diluents were each aseptically transferred to sterile and labeled petri dishes containing the prepared malt extract agar and spread plate technique was used to obtain colonies. Plates were incubated at $30^{\circ} \mathrm{C}$ for 48 hours and the colonies generated were enumerated on a colony counter then recorded [18].

Lactobacilli were determined using MacConkey Rogossa Agar (MRS). Serial dilutions of the brew samples aged 48 hours were done to the $6^{\text {th }}$ dilution factor. Using a sterile pipette $1.0 \mathrm{ml}$ of the diluents was used for a pour plate technique with MRS agar. The media was allowed to set and the petri plates were anaerobically incubated at $37^{\circ} \mathrm{C}$ for 48 hours. Lactobacilli colonies were enumerated after 48 hours on a colony counter and results were recorded [18].

\section{Statistical analysis}

All biochemical, analytical and microbial determinations were done in triplicates. One-way of analysis of variance was used to produce the least significant difference [20].

\section{Results}

The profiles of $\mathrm{pH}$, total acids, alcohol, free reducing sugars and temperature observed during fermentation of opaque beer after using mesh sizes $0.84 \mathrm{~mm}, 1.0 \mathrm{~mm}$ and $1.19 \mathrm{~mm}$ are shown in Figures 1-3 below. Figure 1 shows that the initial amount of free reducing sugars was $7.67 \pm 0.03 \mathrm{mmol} / \mathrm{ml}$ and went down due to microbial fermentation, then leveling-off at $0.37 \pm 0.05 \mathrm{mmol} / \mathrm{ml}$ after $120 \mathrm{hr}$ for mesh sieve of $0.84 \mathrm{~mm}$. The alcohol levels levelled off after $48 \mathrm{hr}$ of fermentation and the $\mathrm{pH}$ gradually went down to 3.3 .

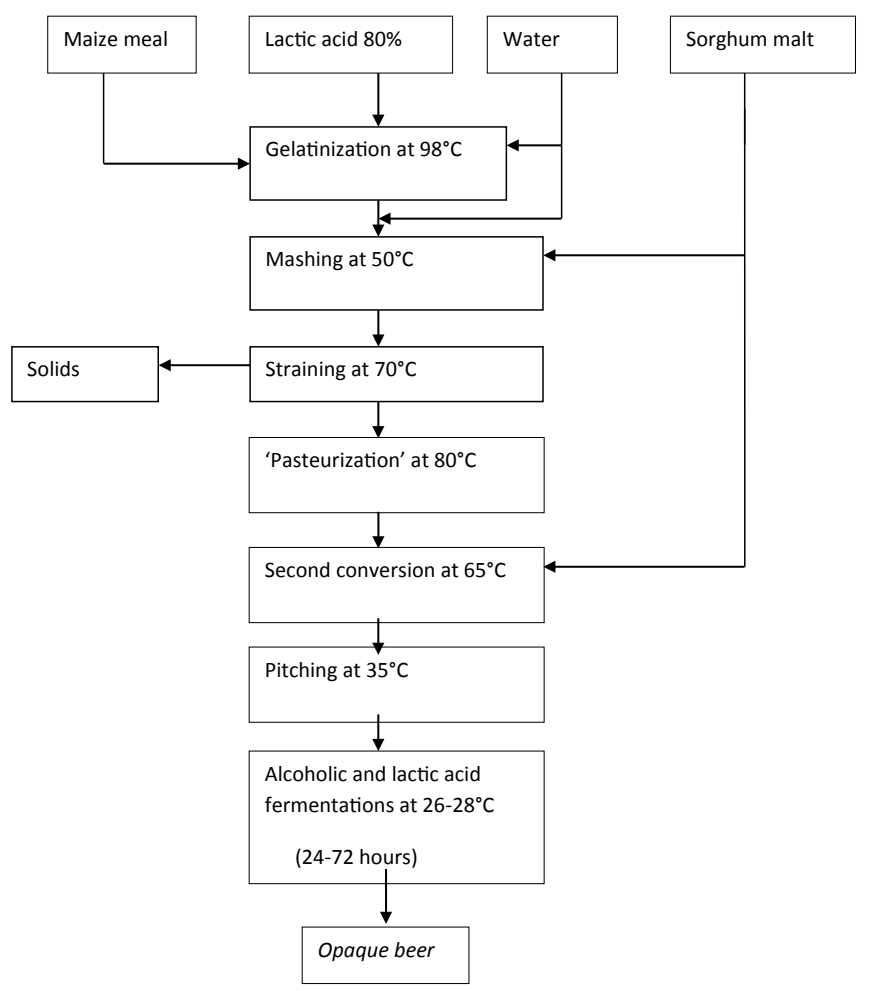

Figure 1: Flow chart to show the commercial production of opaque beer. 


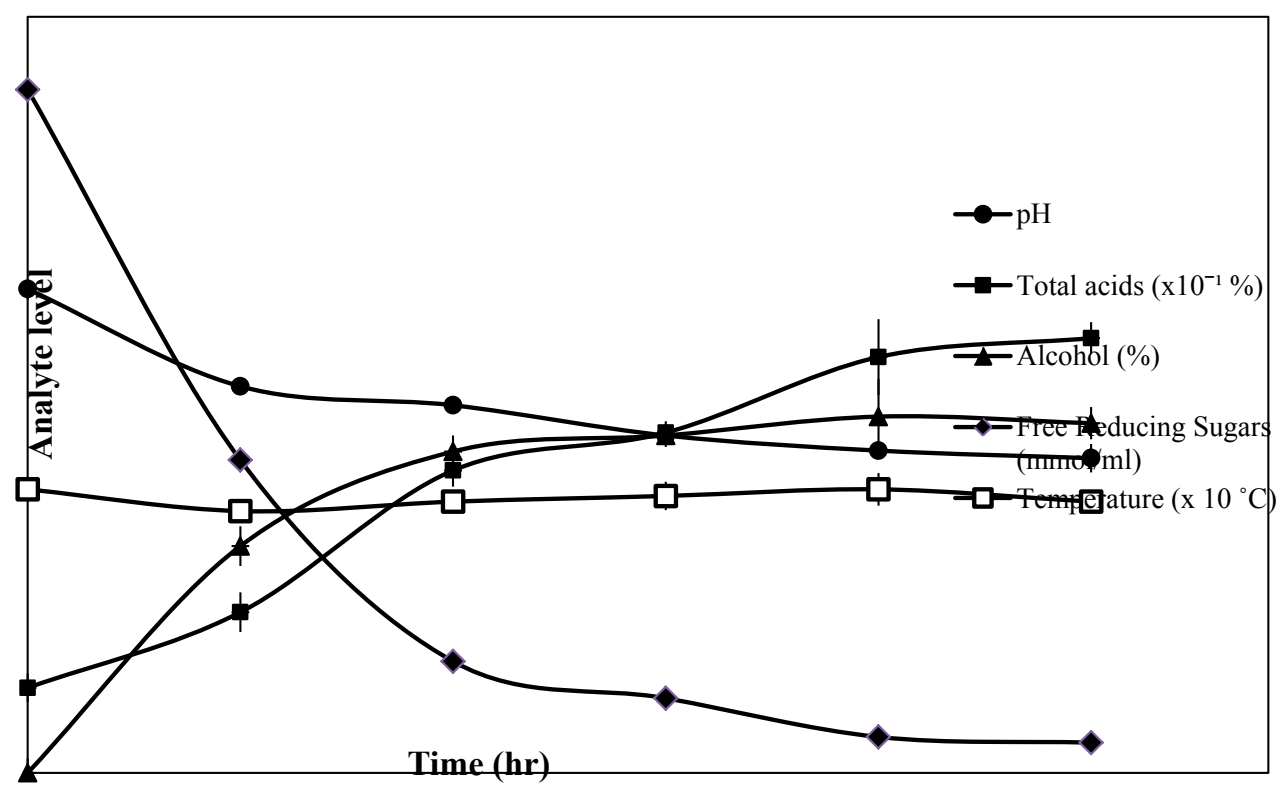

Figure 2: Profiles of $\mathrm{pH}$, total acids, alcohol, free reducing sugars and temperature observed during fermentation of opaque beer after using mesh size 0.84 over a period of $120 \mathrm{hr}$ in a pilot plant of 20 liter.

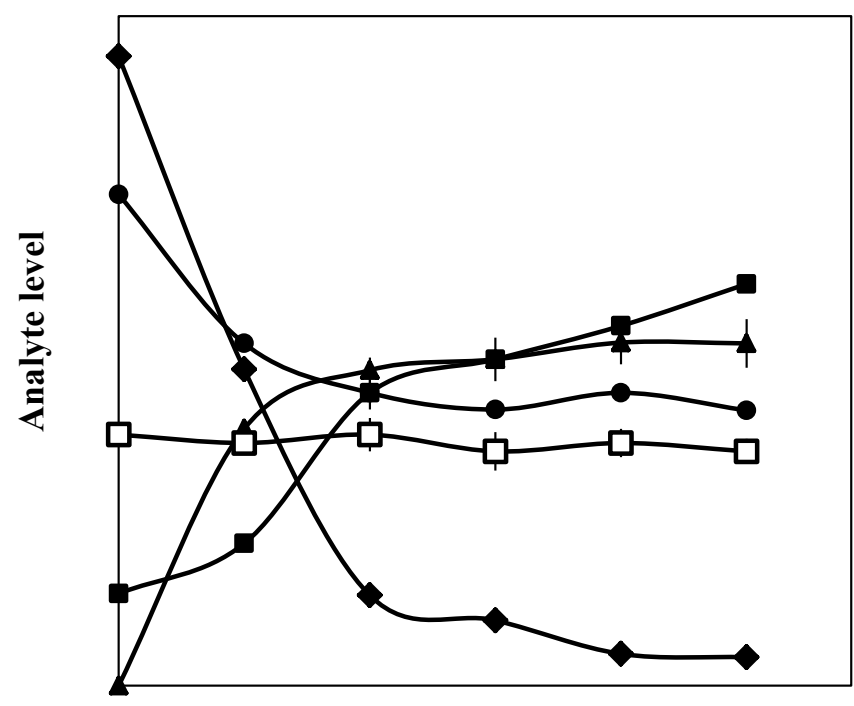

$\rightarrow-\mathrm{pH}$

$\rightarrow$ Total acids $\left(\mathrm{x} 10^{-1} \%\right)$

$\rightarrow$ Alcohol $(\%)$

$\neg$ Free Reducing Sugars $(\mathrm{mmol} / \mathrm{ml})$

$-\square$-Temperature (x 10

$\left.{ }^{\circ} \mathrm{C}\right)$

\section{Time (hr)}

Figure 3: Profiles of $\mathrm{pH}$, total acids, alcohol, free reducing sugars and temperature observed during fermentation of opaque beer after using mesh size $1.0 \mathrm{~mm}$ over a period of $120 \mathrm{hr}$ in a pilot plant of 20 liter.

Figure 2 shows the profiles of the assayed parameters under the same fermentation period of $120 \mathrm{hr}$ for mesh size $1.0 \mathrm{~mm}$. The initial reducing sugars were noted to be slightly higher with this mesh size compared to mesh size $1.19 \mathrm{~mm}$ starting from an initial amount of 7.52 $\pm 0.03 \mathrm{mmol} / \mathrm{ml}$, however resulting at the same content that leveled off at $0.38 \pm 0.06 \mathrm{mmol} / \mathrm{ml}$ after $96 \mathrm{hr}$. A notable difference was the alcohol content that increased equally slightly higher than that produced with mesh size $1.19 \mathrm{~mm}$ which is the recommended utilized mesh sieve size.

Figure 3 shows that the initial reducing sugars were recorded to be $7.23 \pm 0.1 \mathrm{mmol} / \mathrm{ml}$ and were fermented until leveling off at $0.38 \pm$
$0.03 \mathrm{mmol} / \mathrm{ml}$ after $96 \mathrm{hr}$. Thereafter, there was very little remaining of the reducing sugars present in the fermentation vessel. The increase in opaque beer alcohol levels recorded was synonymous with the changes of reducing sugars whereby the sugars were utilized for microbial growth, alcohol and organic acids production. It was recorded that the alcohol concentration increased from 0 to $3.57 \pm 0.06(\mathrm{v} / \mathrm{v}) \%$ levels after $72 \mathrm{hr}$ of fermentation. The temperature of the vessel was noted to fluctuate between 27.7 and $30^{\circ} \mathrm{C}$ for during the entire fermentation period. However, the $\mathrm{pH}$ value dropped from 5.1 to 3.3 due to the production of the lactic acid and other organic acids. It is known that mainly lactic acid is the predominant product of sorghum beer 
Citation: Zvidzai CJ, Chidewe C, Mubaiwa J, Tinofa S, Manjeese W, et al. (2014) Pilot Plant Optimization for Alcohol Production in Fermentation of an Opaque Beer by Varying Sieve Size. Ferment Technol 3: 111. doi:10.4172/2167-7972.1000111

Page 4 of 7

production which was observed to increase from $0.09 \pm 0.02$ to $0.46 \pm$ $0.01(\mathrm{w} / \mathrm{v}) \%$.

Maize milling with mesh size $0.84 \mathrm{~mm}$ produced the highest amount of initial free reducing sugars compared to the other two mesh sizes (Figure 4). The mesh sizes $0.84 \mathrm{~mm}, 1.0 \mathrm{~mm}$ and $1.19 \mathrm{~mm}$ had the following determined initial free reducing sugars at $7.67 \pm 0.03 \mathrm{mmol} /$ $\mathrm{ml}, 7.52 \pm 0.03 \mathrm{mmol} / \mathrm{ml}$ and $7.23 \pm 0.1 \mathrm{mmol} / \mathrm{ml}$, respectively.

Figure 5 shows the corresponding differences among the alcohol content profiles obtained among the three mesh sizes. It was noted that mesh size 1.0 produced a highest alcohol level within a period of $24 \mathrm{hr}$ which amounted to $3.07 \pm 0.12$. The sieve size $0.84 \mathrm{~mm}$ produced the highest alcohol levels with a profile above all the two other mesh sizes. Mesh sieve size $0.84 \mathrm{~mm}$ attained the highest alcohol concentration of $4.47 \pm 0.15(\mathrm{v} / \mathrm{v}) \%$ after $72 \mathrm{hr}$ which was the highest alcohol level attained by all the three mesh types.

Hence, the observed highest reducing sugars when maize is milled with mesh size $0.84 \mathrm{~mm}$ promote highest alcohol production. A comparison of the total lactic acid did not show significant difference
( $>0.05$ ), although mesh size $0.84 \mathrm{~mm}$ showed a slightly higher profile levels compared to the other two.

The temperature profiles in all the opaque brews were observed to fluctuate around $30^{\circ} \mathrm{C}$ during the fermentation period, and had no significant difference $(\mathrm{P}>0.05)$. The microbial counts of lactic acid bacteria (Lactobacillus sp.) and S. cerevisiae after $48 \mathrm{hr}$ had marked difference among the fermented beers as noted from Table 1 below.

It was recorded that all the brews the same amount of free reducing sugars after $96 \mathrm{hr}$ of fermentation had regardless of the mesh size used to produce the adjunct during maize milling. However, the total organic acids obtained did not show a marked difference in the final concentration when the mesh size was increased. It can be noted that change of mesh size during milling of maize for preparation of adjuncts for opaque beer preparation will only increase the free reducing sugars, alcohol content and microbial counts but will not affect the total organic acids. There were no significant differences among the profiles of the lactic acid production $(\mathrm{P}>0.05), \mathrm{pH}$ and temperature from the three mesh sizes.

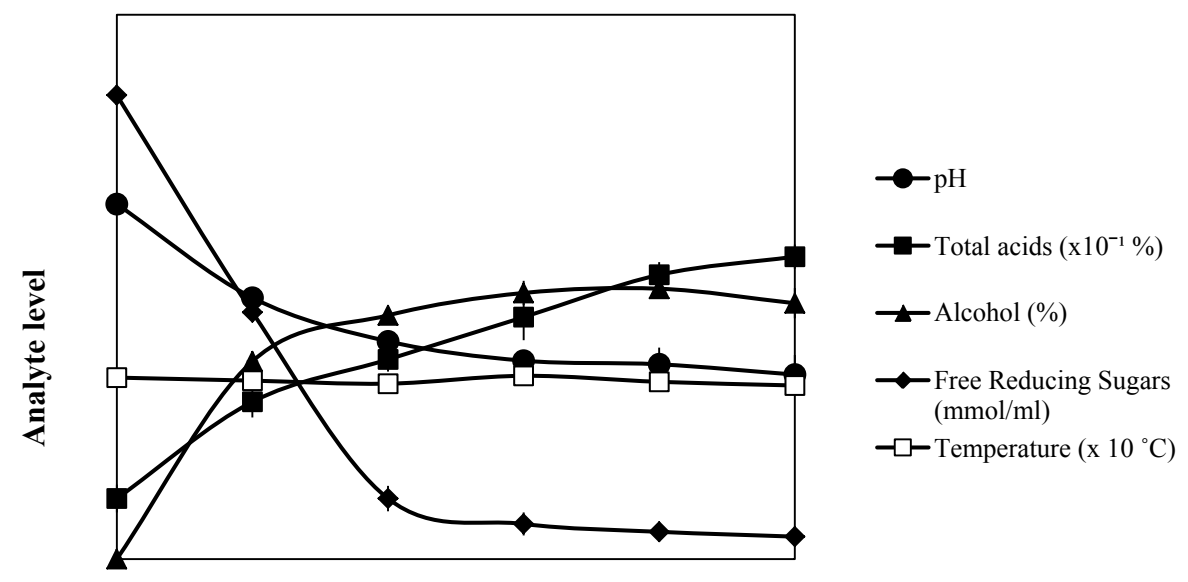

Time (hr)

Figure 4: Profiles of $\mathrm{pH}$, total acids, alcohol, free reducing sugars and temperature observed during fermentation of opaque beer after using mesh size 1.19 over a period of $120 \mathrm{hr}$ in a pilot plant of 20 liter.

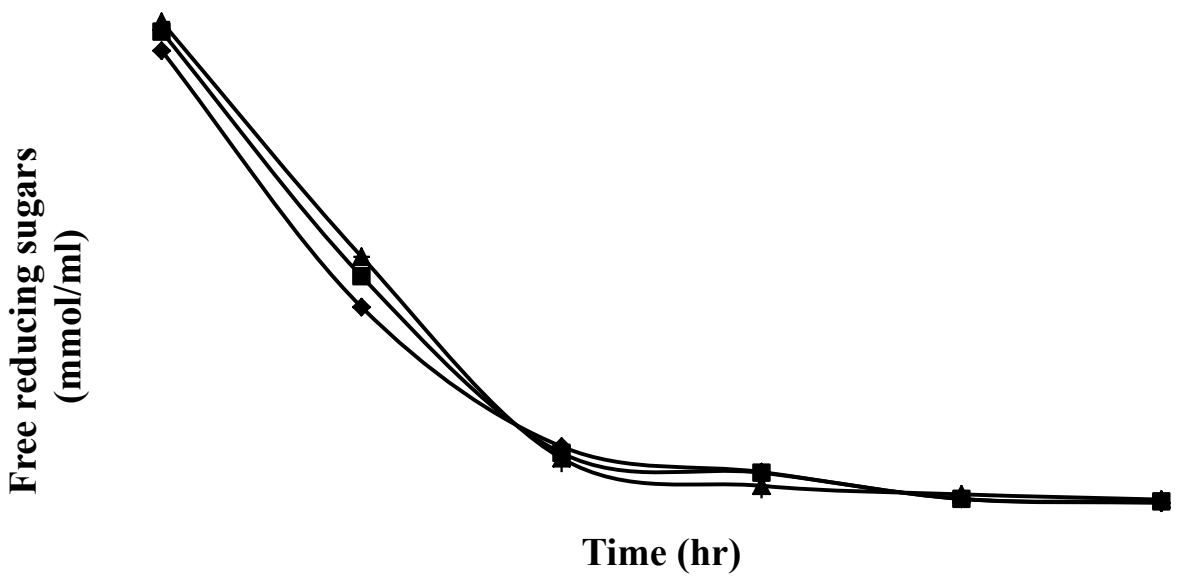

Figure 5: Free reducing profiles obtained from mesh sizes $1.19 \mathrm{~mm}(\boldsymbol{\Delta}), 1.0(\mathbf{\square}) \mathrm{mm}$ and $0.84 \mathrm{~mm}(\bullet)$. 


\begin{tabular}{|c|c|c|c|}
\hline Microorganism & $\begin{array}{c}\mathbf{0 . 8 4} \mathbf{~ m m ~ m e s h} \\
\text { size }\end{array}$ & $\begin{array}{c}\mathbf{1 . 0} \mathbf{~ m m ~ m e s h} \\
\text { size }\end{array}$ & $\begin{array}{c}\mathbf{1 . 1 9} \mathbf{~ m m ~ m e s h} \\
\text { size }\end{array}$ \\
\hline Lactobacillus sp. $\left(\times 10^{-6}\right)$ & $16 \pm 0.4$ & $7 \pm 0.3$ & $3 \pm 0.1$ \\
\hline S. cerevisiae $\left(\times 10^{-2}\right)$ & $14 \pm 0.3$ & $10 \pm 0.2$ & $4 \pm 0.2$ \\
\hline
\end{tabular}

Table 1: Microbial count of the opaque beer products after $48 \mathrm{hr}$ of fermentation produced from mesh sizes $0.84,1.0$ and $1.19 \mathrm{~mm}$.

\section{Sensory evaluation}

The sensory attributes of the three varied sorghum beer brews were determined by the producing company's panelist and the results are summarized on the spread web in Figure 6 below. The brew from sieve $1.0 \mathrm{~mm}$ had the head creaminess; brand identity and thickness closest to the commercial product although it shared bite and texture properties. However, the brew from sieve size 0.84 had the best head retention characteristic of the commercial product. Although 0.84 produced the highest ethanol concentration it was not the preferred brew among the three. Considering the head creaminess, bite, head retention and texture as fundamental properties of opaque beer the most closest to the commercialized brand is that from $1.0 \mathrm{~mm}$ grits prepared with sieve size $1.0 \mathrm{~mm}$ Figure 7.

\section{Discussion}

It was interesting to note that mesh sieve size affected the initial sugar levels. Geometric mean diameters decreased with mesh size 1.19 $\mathrm{mm}$ followed by $1.0 \mathrm{~mm}$ and $0.84 \mathrm{~mm}$ screens, respectively. The highest reducing sugar concentrations were achieved with the lowest particle mesh sieve size of $0.84 \mathrm{~mm}$. The normal mesh used for industrial sieving of maize grits was compared to opaque brew produced with the sieves of $0.84,1.0$ and $1.19 \mathrm{~mm}$. It was observed that increased the reducing sugars concentration by 4 and $6 \%$ respectively. It was observed that high initial reducing sugars promote high ethanol level productions as was the case with smaller sieve sizes. The $\mathrm{Q}_{\mathrm{p}}$ values calculated of ethanol volumetric productivity were $0.49,0.54$ and $0.61 \mathrm{~g} . \mathrm{l}^{-1} \cdot \mathrm{h}^{-1}$ respectively. Such volumetric productivity with $1.0 \mathrm{~mm}$ sieve had an increase in ethanol concentration by $9 \%$. Although all the beer brews were noted to have alcohol which was within the acceptable levels, however, the beer that produced a higher alcohol level of $4.23 \pm 0.25(\mathrm{v} / \mathrm{v}) \%$ with mesh size $0.84 \mathrm{~mm}$ had an increase of ethanol concentration by $23 \%$. Such an increase of ethanol concentration with a smaller mesh size has been equally reported to be a fundamental parameter for opaque beer fermentation process using unmalted grains [21]. This realized a Yp/s value increase of $2 \%$ with the use of $1.0 \mathrm{~mm}$ sieve and $4 \%$ with $0.84 \mathrm{~mm}$. It has been noted that the smallest sieve size allows more surface area of crystalline structure of starch granules to get exposed and furnish with more free reducing sugars during gelatinization of boiling stage and amylolysis processing [14].

The final ethanol concentrations of all the brews are within the normal levels. Other researchers have noted that alcohol content of opaque sorghum beer range between $2-4(\mathrm{v} / \mathrm{v}) \%[13,22]$. Naidu et al. produced same trend of results observing an increase of ethanol yield when corn particle sizes decreased [23]. Similar results were observed elsewhere because large starch granules form fewer fermentable sugars [24]. However, these workers obtained quite high ethanol levels of around 10-12\% (v/v) using mesh sizes of $0.5 \mathrm{~mm}$. These ethanol concentrations are synonymous with high gravity fermentation. It is here, noted that liquefaction was improved from the high amylase activity of the sorghum inoculum. Use of finer flour has been recommended to increase surface area that would provide more soluble substrates thereby accelerating fermentation [25]. The rate of milled cereals enzymatic hydrolysis has been reported elsewhere and to be surface area depended too [26]. In addition, high concentrations of total soluble and fermentable sugars have been reported in fine grits compared to coarse grits [27]. Overall optimizing ground corn/maize grits particle to fine flour size allows maximum ethanol yield during fermentation. The viscosity of the beer wort prior to fermentation was within the operation limits of the plant since we did not use sieve sizes lower than 1.0 which have been associated with high viscosity and clogging of filters observed by other researchers [14,22].

However, similar trend of finer sieves for increased ethanol levels results have been observed when cellulosic biomass of Miscanthus giganteus (Miscanthus) was subjected to hammer milling processing for ethanol production [28]. In contrast, Zhua and others (2009) reported smaller average particle sizes produced by dry milling did not produce elevated amounts of glucose or ethanol during cellulose hydrolysis [29].

The lactic acid profile produced by three mesh sieves was almost the same and hence it was noted that sieve size does not have an effect on the final lactic acid level. Since there was no significant different $(\mathrm{P}>0.05)$ on the total lactic acids among the brews of the different sieve

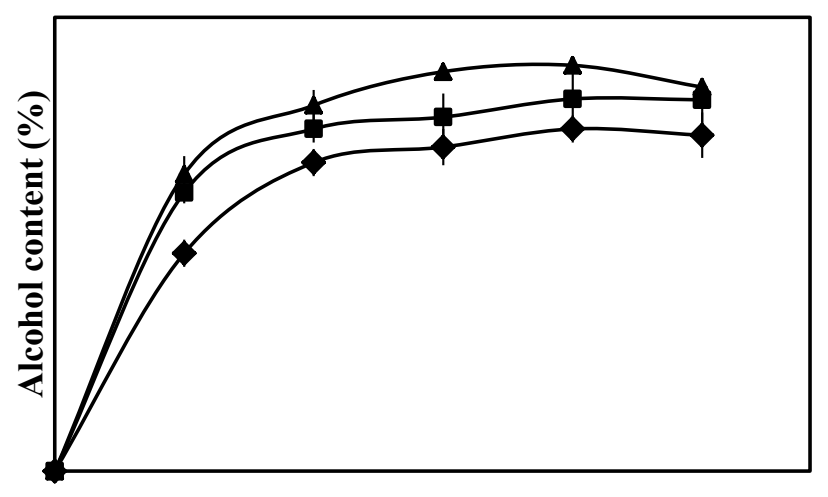

Time (hr)

Figure 6: Alcohol profiles of fermentation from mesh size $1.19 \mathrm{~mm}(\bullet), 1.0$ $\mathrm{mm}(\mathbf{\square})$ and $0.84 \mathrm{~mm}(\boldsymbol{\Delta})$ over a period of $120 \mathrm{hr}$ in a pilot plant of 20 liter.

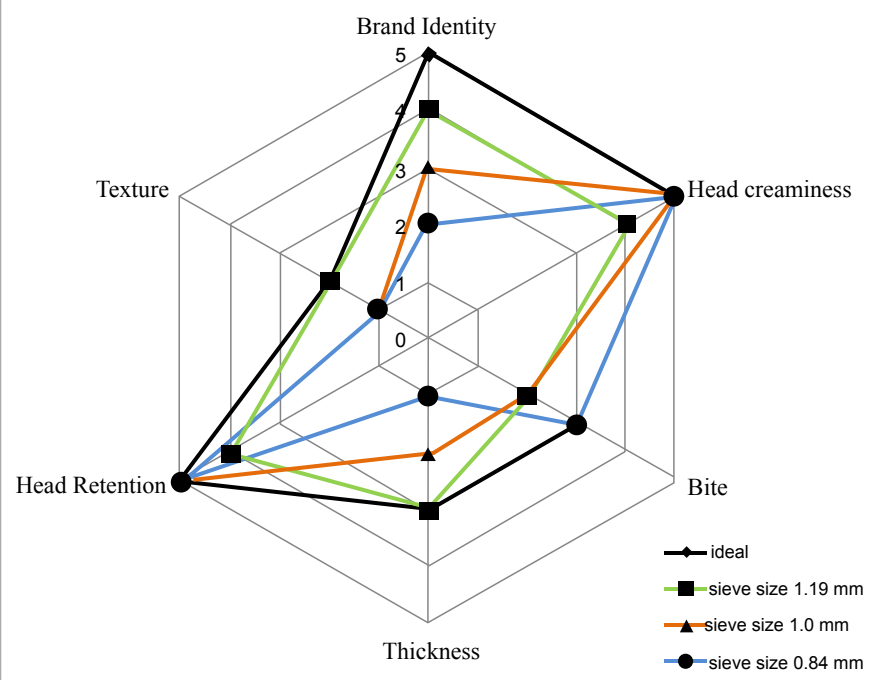

Figure 7: Spread web analysis of the sensory results of the brew brands produced from different sieve sizes. 
Citation: Zvidzai CJ, Chidewe C, Mubaiwa J, Tinofa S, Manjeese W, et al. (2014) Pilot Plant Optimization for Alcohol Production in Fermentation of an Opaque Beer by Varying Sieve Size. Ferment Technol 3: 111. doi:10.4172/2167-7972.1000111

Page 6 of 7

sizes, it similarly reflected likewise on the $\mathrm{pH}$ profiles. Although the final lactic acid bacteria content were quite different, this was contrary to the concentration of lactic acid concentrations recorded in the fermentation cultures.

The observed microbial growth of yeasts and lactic acid bacteria has been similarly accounted for in sorghum beer production by other workers [30,31]. The highest yeast cell count in brew of sieve size 0.84 $\mathrm{mm}$ produced the highest alcohol concentration. As the mesh sieve got reduced there was an increase of microbial counts which tallied with the organic acids production and alcohol production. Such organic acid production and alcohol production is synonymous with Lactobacillus sp. and Saccharomyces cerevisiae that was observed with other researchers elsewhere [3,5,25,31-34]. However, it should be realized that Lactobacillus sp. producing microbes are rather diverse in opaque beer production each species with varying fermentation capacities $[31,35]$.

A combination of commercial enzymes and diastatic power from sorghum malt has been attributed to increased ethanol levels rather relying on natural diastatic power from the sorghum malt only [14]. It was interesting to note that the three beer brews produced were acceptable by the sensory evaluation panelist who gave a high score rating on the quality of the product based on appearance, taste, consistence, thickness, colour, smell, head retention and mouth feel compared to the commercial product.

\section{Conclusion}

The free reducing sugars increased gradually from as the sieve sizes increased due to increased surface area for gelatinization and amylolysis processes. It was noted that ethanol concentration increased as the mesh size decreased, with alcohol levels that were attained leveling off at around $4 \%(\mathrm{v} / \mathrm{v})$ for all the mesh sieve sizes after $72 \mathrm{hr}$. Overally, the $\mathrm{pH}$ was noted to drop to 3.3 in all cases. The grinding sieve size increased ethanol levels by $9 \%$ and $23 \%$ when maize grits were obtained with 1.0 and $0.84 \mathrm{~mm}$, respectively. However, it was recommended that mesh sieve $1.0 \mathrm{~mm}$ was the optimized maize adjuncts producing grits that will have a consistent opaque beer product that is acceptable and is of palatability taste for consumption according to sensory evaluation done.

\section{References}

1. Owuama Cl (1997) Sorghum: a cereal with lager beer brewing potential. W. J. Microbiol. Biotechnol 13: 253-260.

2. Lee WJ, Pedersen JF, Shelton DR (2002) Relationship of Sorghum kernel size to physiochemical, milling, pasting, and cooking properties. Food Res. Int 35: 643-649.

3. Kayodé APP, Hounhouigan DJ, Nout MJR, Anke N (2007) Household production of sorghum beer in Benin: technological and socio-economic aspects. Int. J. Consumer Studies 31: 258-264.

4. Odunfa SA, Adeyele S (1985) Microbiological changes during the traditional production of ogi-baba, a West African fermented sorghum gruel. J. Cereal Sci 3: $173-180$.

5. Odunfa SA (1985) African Fermented Foods. In: Microbiology of Fermented Foods, Vol 2, Wood, B.J. (ed) Elsevier Applied Science Publishers. London \& New York.

6. Daiber KH and Taylor J RN (1995) Opaque beers. In Sorghum and Millets: Chemistry and Technology, (D. A V Dendy, ed), American Association of Cereal Chemists, USA: 299-323.

7. Kyarisiima CC, Okot MW, Svihus B (2004) Use of wood ash in the treatment of high tannin sorghum for poultry feeding. S. Afri. J. Animal Sci 34: 110-115.

8. Taylor JRN, Belton PS (2002) Sorghum in Pseudocereals and Less common
Cereals Grain Properties and Potential Utilization. Eds Belton P S and Taylor J R N. Springer $25-79$.

9. Belton PS, Taylor JRN (2004) Sorghum and millets: Protein sources for Africa Trends Food Sci. Tech. 15: 94-98.

10. Chavan JK, Kadam SS (1989) Nutritional improvement of cereals by sprouting Crit. Rev. Food Sci. Nutrition. 28: 401-437.

11. Steinkraus KH (1996) Handbook of Indigenous Fermented Foods. $2^{\text {nd }}$ edn, New York.

12. Okafor N, Umeh C, Ibenegbu C, Obizoba I, Nnam N (1998) Improvement of garri quality by the inoculation of microorganisms into cassava mash. Int. J. Food Microbiol 40: 43-49.

13. Briggs DE, Boulton CA, Brookes PA, Stevens R (2004) Native African beers In Brewing Science and Practice (ed. by R. Stevens), CRC Press, Woodhead Publishing Ltd, Cambridge: 589-605.

14. Barcelos CA, Maeda RN, Betancur GJV, Pereira N Jr (2011) Ethanol production from sorghum grains [Sorghum bicolor (L.) Moench]: Evaluation of the enzymatic hydrolysis and the hydrolysate fermentability. Braz. J. Chem. Eng 28: 597-604.

15. Odunfa SA (1989) Cereal fermentations in African countries. In Fermented cereals: a global perspective. Satin M., (ed). FAO Agricultural Services Bulletin No. 138. Rome, Italy.

16. Beta T, Corke H, Taylor JRN (2000) Starch properties of Barnard Red, a South African red sorghum variety of significance in traditional African brewing Starch/Stärke 52:467-470.

17. Zhan X, Wang D, Tuinstra MR, Bean S, Sieb PA, et al. (2003) Ethanol and lactic acid production as affected by sorghum genotype and location. Ind. Crops Products 18: 245-255.

18. Delta Beverages (2000) Investigation of shelf-life extension of sorghum beer (Chibuku) by removing the second conversion of malt, Zimbabwe: 1-60.

19. Horwitz, William, AOAC, (1995) Official methods of analytical chemists, $14^{\text {th }} \mathrm{ed}$ Washington DC: $125-898$.

20. Gomez AK, Gomez AA (1984) Statistical procedures for agricultural research $2^{\text {nd }}$ ed. New York, John Wiley: 7-240.

21. Goode DL, Arendt EK (2003) Pilot scale production of a lager beer from a grist containing $50 \%$ unmalted sorghum. J. Inst. Brew. 109: 208-217.

22. Agu RC, Palmer GH (1998) A reassessment of sorghum for lager-beer brewing Bioresource Technol 66: 253-261.

23. Naidu K, Singh V, Johnston DB, Rausch KD, Tumbleson ME (2007) Effects of ground corn particle size on ethanol yields and thin stillage soluble solids. Cereal Chem 84: 6-9.

24. Kelsall DR, Lyons TP (2003) Grain dry milling and cooling procedures: Extracting sugars in preparation for fermentation. In The alcohol Textbook: $A$ reference for the beverage, fuel and industrial alcohol industries. $4^{\text {th }} \mathrm{ed}$. Jaques K. A., Lyons T. P. and Kelsall D. R. (ed). Nottingham University Press. Nottingham, UK.

25. Abegaz K, Langsrud T, Beyene F, Narvhus JA (2004) The effects of technologica modifications on the fermentation of borde, an Ethiopian traditional fermented cereal beverage. The J. Food Technol. Afri 9: 3-12.

26. Aggarwal $P$, Dollimore D (1998) A thermal analysis investigation of partially hydrolyzed starch. Thermochim. Acta. 319: 17-25.

27. Lasekan OO, Idowu MA, Lasekan W (1995) Effect of germination and degree of grind (coarse/fine) on the extract and sugar content of sorghum malts. Food Chem. 58: 125-128.

28. Khullar E (2012). Miscanthus conversion to ethanol: effect of particle size and pretreatment conditions for hot water. University of Illinois at UrbanaChampaign, USA: 1-97.

29. Zhua YJ, Wangb GS, Panc XJ, Gleisnera R (2009) Specific surface to evaluate the efficiencies of milling and pretreatment of wood for enzymatic saccharification. Chemical Engineering Science 64: 474-485.

30. Sridee W, Laopaiboon L, Jaisil P, Laopaiboon P (2011) The use of dried spent yeast as a low-cost nitrogen ethanol fermentation from sweet sorghum juice under very high gravity conditions. Electronic Journal of Biotechnology.

31. Kayodé APP, Vieira-Dalodé G, Linnemann AR, Kotchon SO, Hounhouigan AJD, 
Citation: Zvidzai CJ, Chidewe C, Mubaiwa J, Tinofa S, Manjeese W, et al. (2014) Pilot Plant Optimization for Alcohol Production in Fermentation of an Opaque Beer by Varying Sieve Size. Ferment Technol 3: 111. doi:10.4172/2167-7972.1000111

Page 7 of 7

et al. (2011) Diversity of yeasts involved in the fermentation of tchoukoutou, an opaque sorghum beer from Benin. Source African Journal of Microbiology 5: 2737-2742.

32. Ojokoh AO (2009)A comparative study on the effect of traditional and improved methods of fermentation in the production of Ogi food. Oriental Journal of Chemistry 25: 471-476

33. Ekundayo JA (1969). The production of pito, a Nigerian fermented beverage. Int. J. Food Sci. Tech 4: 217-225.
34. Hutjens MF, HM Dann (2000) Grain processing: is it too coarse or too fine?

35. Ali AA, Mustafa MM (2009) Isolation, characterisation and identification of lactic acid bacteria from fermented sorghum dough used in Sudanese Kisra preparation. Pakistan Journal of Nutrition 8: 1814-1818.

This article was originally published in a special issue, Microbia

Fermentation for Production of Biofuels handled by Editor(s). Dr. Manoi

Agrawal, Georgia Institue of Technology, USA 